\title{
First results of varios sour cherry cultivar on Oblacsinska as interstocks and Prunus mahaleb rootstocks
}

\author{
Davarynejad, G.H. ${ }^{1}$, Nyéki, J. ${ }^{2}$, Davarynejad, E. ${ }^{1}$, Szabó, T. ${ }^{3}$ \& Szabó, Z. ${ }^{2}$

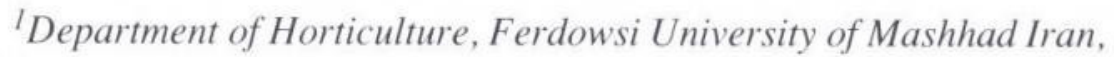 \\ ${ }^{2}$ University of Debrecen, Institute for Research and Development, Hungary, \\ ${ }^{3}$ Fruit Research and Extension Institute, Úifehértó
}

Summary: At the experiment orchard of the Fruit Research and Extension Institute, Ujfehértó, Hungary in spring 2000 a trial was designed included: Érdi bổtermố, Debreceni bổtermố, and Csengốdi sour cherry (Prunus avium L) cultivars which were budded at 1999 on Oblacsinszka sour cherry (as a dwarf inter stock), which had been budded on Prunus mahaleb seedlings at 1998 with the aim to investigate the dwarfing effects of Oblocsinszka sour cherry cultivars on scion cultivars. Trees of each cultivar directly on Prunus mahaleb seedling, severd as controls. Use of Oblacsinska as an interstock reduced the rootstock trunk diameter. Trees of Debreceni bốtermổ, and Csengốdi sour cherry cultivars with Oblacsinska interstock were smaller than similar trees grafted directly onto Prunus mahaleb as a rootstock. Trees of Érdi bổtermố grafted on Oblacsinszka interstock which buded on Prunus mahaleb were the smallest. Growth of the trees was reduced also by using of the Oblacsinszka as interstock for other examined cultivars.

Key words: sour cherry, Oblacsinska, Prunus mahaleb, interstocks, rootstocks

\section{Introduction}

The fruit growers prefer to have dwarf trees in intensive orchard, because of advantages of better harvesting, disease and pest control. Interstocks of dwarfing rootstock clones have proved much or less reliable in reducing scion vigor. The earliest reports on cherry rootstocks, citied by Anthony et al. (1937), Webster \& Schmidt (1996) reported that interstocks improving the yield productivity of cherry scions. Previous investigation by Bujdosó et al. (2004) showed that in intensive cherry orchards the moderately vigorous rootstocks gave the best yields and fruit quality. Rootstocks, interstocks and scions may effect several cherry tree performance parameters, including growth characteristic, tree size, fruit bud survival, fruit quality, yield and yield efficiency (Larsen, 1970; Westwood et al., 1976; Larsen \& Patterson, 1981; Millikan \& Hibbard, 1984, Stebbins \& Cameron, 1984; Holb \& Schnabel, 2005). Extensive breeding efforts and using of interstocks in several countries have succeeded in introducing size-controlling rootstocks and interstocks over a wide range of vigor (Bryant, 1939; Rozpara et al., 1998; Tabel, 2005; Hrotkó \& Simon, 1996; Hrotkó et al., 1997, 1998).

In response to the problem of vigor control in existing orchards this study was designed to investigate the vegetative and reproductive habit and the effects of Oblacsinszka as a dwarfing interstock on scion, rootstock, tree vigor, yield, trunk cross-sectional area and yield efficiency of some sour cherry cultivars after 8-year period of planting, in the north part Hungary.

\section{Materials and methods}

The experiment included Érdi bốtermố, Debreceni bốtermố, Csengổdi, sour cherry cultivars grafted at 1999 on Oblocsinszka which were budded on Prunus mahaleb at 1998. The orchard is situated on a sandy soil with low $(0.9 \%)$ humus content at Újfehértó between the Debrecen and Nyereghaza, Hungary. The $\mathrm{pH}$ of the soil was 7.5. with 4 trees per plot for a total of 12 trees of each scion/interstock/ rootstock combinations. Prunus mahaleb used as a rootstock and Oblacsinska sour cherry cultivar as an interstock (over $P$. mahaleb seedling rootstocks). Sour cherry cultivars were grafted on interstocks and planted at March 2000 at $7 \times 5 \mathrm{~m}$ (275 trees/ha). Trees of each cultivar on Prunus mahaleb seedlings, without an interstem, served as controls. The whole interstock part $(30 \mathrm{~cm})$ was above soil line.

The experimental orchard was not irrigated and the average annual precipitation in this area was about $600 \mathrm{~mm}$. The trees were trained as free spindles with central leader. Soil management includes frequent grass moving in the alleyways in conjunction with the maintenance of $1-\mathrm{m}$ wide herbicide strips along the tree rows.

Tree vigor, crown cross-sectional area (CCSA) of rootstock (below the first grafting union), interstock trunk cross-sectional area (ITCSA) (between two grating), Trunk cross-sectional area (TCSA), $(10 \mathrm{~cm}$ above the second graft union), Specific yield $\mathrm{kg} / \mathrm{cm}^{2}$ trunk sectional area, stem height, tree height and width, the area under-canopy $\left(\mathrm{m}^{2}\right)$, canopy volume $\left(\mathrm{m}^{3}\right)$, beginning of flowering, full bloom, Post blooming time, ripening time and other phonological 
observation (flower density) were recorded, when the trees had reached their final size at the eight leaf stage, in the evaluation plots.

Data were analyzed statistically using a $3 * 2$ factorial design based on completely randomized design. Analysis of variance and Duncan's multiple range test $(\alpha=0.05)$ was provided using the MSTATC program. Analysis of variance and Duncan's multiple range test $(\alpha=0.05)$ was provided using the MSTATC program.

\section{Results and Discussion}

\section{Crown cross-sectional area of rootstock}

Crown cross-sectional area (CCSA) of rootstock are presented in Figure 1. The CCSA of Prunus mahaleb, as root stock, when grafted by Oblacsinska interstock and Érdi bốtermố as cultivar, significantly (3 times) was smaller in comparison with CCSA of Prunus mahaleb when directly buded by Érdi bốtermố. The CCSA of tree of Debreceni bốtermô/Oblacsinska/Prunus mahaleb was smaller than Debreceni bốtermô/Prunus mahaleb. In the case of Csengổdi/Oblacsinska/Prunus mahaleb in comparison with Csengôdi/Prunus mahaleh, the CCSA also was smaller. It means that the Oblacsinska interstock inhibit the growth of root crown area of Prunus mahaleb. Use of 'Oblacsinka' as an interstock highly reduced the rootstock crown diameter. In all combinations a sizeable swelling forms on the graft union with Oblacsinska sour cherry on $P$. mahaleb.

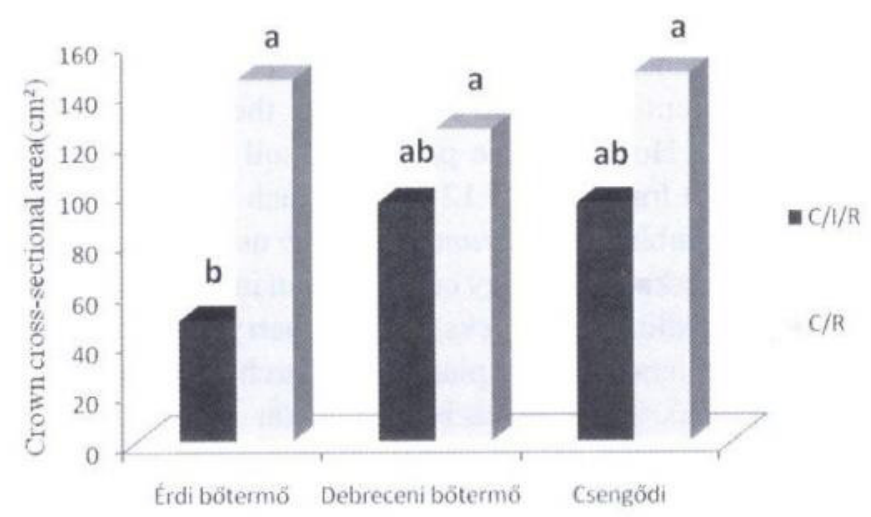

Figure 1. Effects of interstock on CCSA of rootstock of sour cherry cultivars Legend: $\mathrm{C} / \mathrm{I} / \mathrm{R}=$ Cultivar buded on Interstock which buded on Prunus mahaleb $\mathrm{C} / \mathrm{R}=$ Cultivar directly buded on Prunus mahaleb

\section{Inter stock cross-sectional area (ITCSA)}

The length of Oblacsinska as an interstock was between $30-40 \mathrm{~cm}$ but its ITCSA differs with the combination with the scion cultivars. (Figure 2). The results shows that the ITCSA of Érdi bốtermổ cultivars were bigger than CCSA of root stocks and TCSA of scion (cultivar), while in the case of Debreceni bốtermố The ITCSA was bigger than CCSA and smaller than TCSA. In combination of Csengôdi/ Oblacsinska/Prunus mahaleb the ITCSA is approximatly the same size as CCSA and TCSA. In all combinations a sizeable swelling forms on the graft union with Oblacsinska sour cherry on $P$. mahaleb. This swelling occurs below the graft union. Similar observations were made with the interstock which was thinner than the crown of rootstock ( $P$. mahaleb) and the TCSA of scion cultivar used. It means that the trunk of the tree seems bad configuration (malformed) of appearance. The largest ITCSA diameter, over the eight years period was recorded for the Érdi bổtermổ trees; the least was recorded on the Csengốdi grafted on Prunus mahaleb.

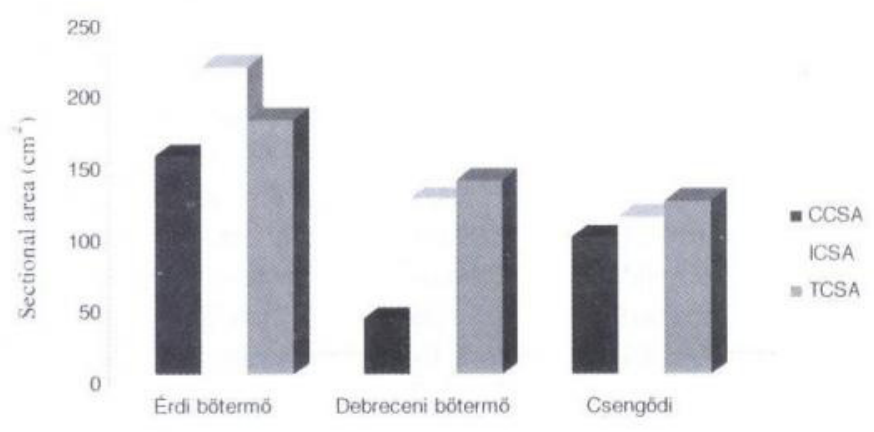

Figure 2. Cectional area of crown (root stock), interstock and trunk (sion) of sour cherry cultivars

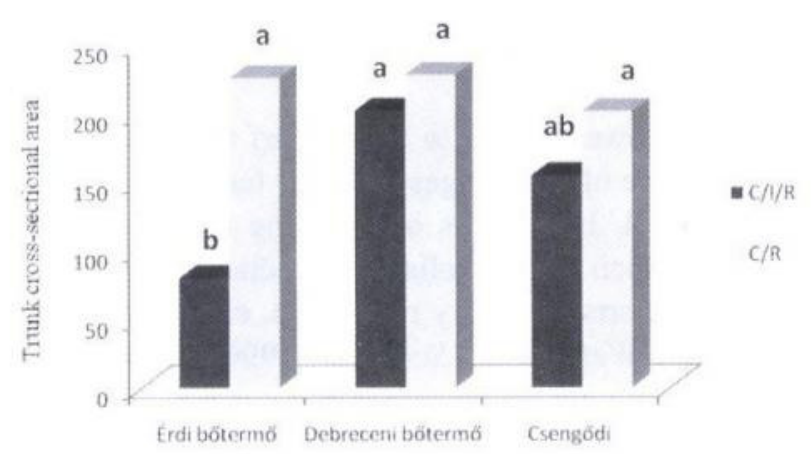

Figure 3. Effects of interstock on TSA of sour cherry cultivars Legend: $\mathrm{C} / \mathrm{I} / \mathrm{R}=$ Cultivar buded on Interstock which buded on Prumus mahaleb $\mathrm{C} / \mathrm{R}$ $=$ Cultivar directly buded on Prunus mahaleb

\section{Trunk cross-sectional area (TCSA)}

Intrstock of Oblacsinska limited growth as measured by TCSA of all examined sour cherry cultivars (Figure 3). The significant differences of TCSA of Tree Cultivar Érdi bổtermổ/ Oblacsinska/ Prunus mahaleb was $46.5 \mathrm{~cm}^{2}$, while TCSA of this cultivar directly on Prunus mahaleb was 3,1 time $(143,5)$ bigger. Trees grafted on Prumus mahaleb seedlings whit Oblacsinska interstock grew weaker than those grafted on Prunus mahaleb directly. There was no signicant differences between the TCSA of Debreceni bốtermổ and Csengổi trees when was grafted on interstock whit in the case of directly grafted on Prumus mahaleb.

The area under-canopy was also affected by Oblacsinska as interstock being shorter than control trees. the area under tree canopy of sour cherry cultivars/ interstock/ 
rootstock are presented in Figure 4. The area under tree canopy of Érdi bốtermố/Oblacsinska/Prunus mahaleb significantly ( 3 times) was smaller in comparison with Érdi bốtermổ when directly buded on Prunus mahaleb.

The area under-canopy of Debreceni bốtermô/ Oblacsinska/Prunus mahaleb was smaller than Debreceni bôtermô/Prunus mahaleb. In the case of Csengôdi/ Oblacsinska/Prunus mahaleb in comparison with Csengôdi/ Prunus mahaleb, the area under-canopy also was smaller. It means that the Oblacsinska interstock inhibit the growth and spreed of shoot of the trees. Our results were agreed with the result obtained by Hrotkó et al. (1997). They fund that; scions of sweet cherry may be dwarfed by grafting on to dwarfing rootstocks. The dwarfing effect of the rootstock may also be induced by a stem piece or interstock, grafted between a scion and rootstock.

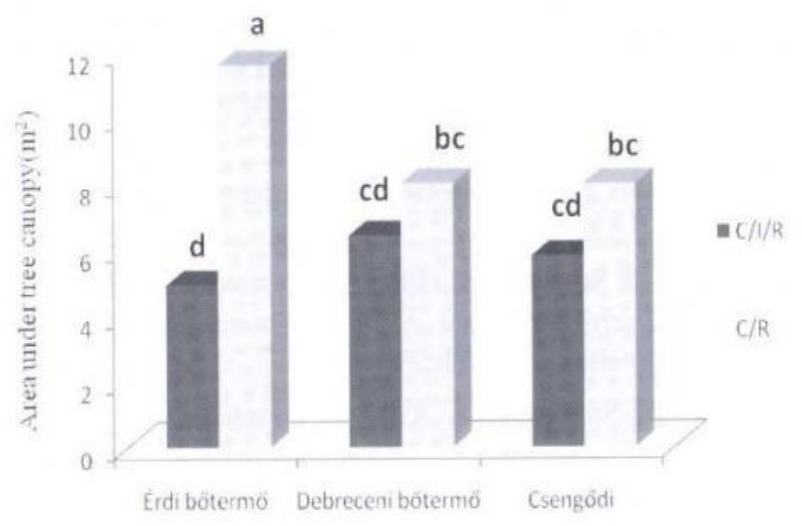

Figure 4. Effects of interstock on the area $\left(\mathrm{m}^{2}\right)$ under tree canopy of sour cherry cultivars Legend: $\mathrm{C} / \mathrm{I} / \mathrm{R}=$ Cultivar buded on Interstock which buded on Prumus mahaleb $\mathrm{C} / \mathrm{R}=$ Cultivar directly buded on Prumus mahaleb

\section{Canopy volume}

Interstem also modified canopy size. The control tree of Érdi bốtermô/Prumus mahaleb had biggest canopy volume after eight years. The smallest canopy occurred on Érdi bốtermổ grafted with Oblacsinska as interstem which was grafted on Prunus mahaleb as seedling. Also the Csengódi tree with interstock of Oblacsinska/Prunus mahaleb in comparison with Csengôdi directly on Prumus mahaleb was significantly smaller canopy volume (Figure 5). The canopy volume of Debreceni bốtermô/Oblacsinska/Prunus mahaleb was smaller than Debreceni bốtermó/Prunus mahaleb. This results are agree whit the results of Larsen (1970) and Stebbins \& Cameron (1984). Thay bleave that interstocks and scions may effect several cherry tree growth characterics and tree size. Whit respect to Canopy volume from the various evaluative trials, Érdi bốtermố/ trees on Oblacsinska interstock on Prunus mahaleb rootstock were $30 \%$ less vigorous than directly on Prunus mahaleb (Figure 5).

\section{Production kg/tree}

No significant effects of interstock grafting were found on Specific yield $\mathrm{kg} /$ tree of each cultivar at harvest. While

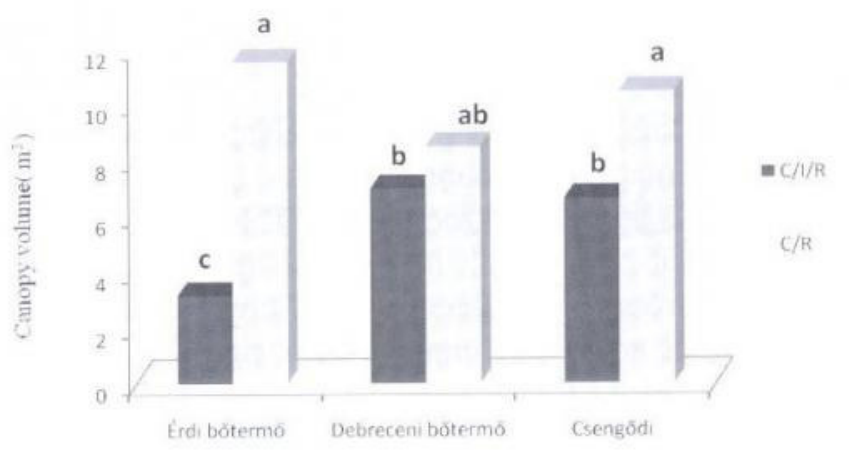

Figure 5. Effects of interstock on Canopy volume $\left(\mathrm{m}^{3}\right)$ of sour cherry cultivars Legend: $C I I / R=$ Cultivar buded on Interstock which buded on Prumus mahaleb $\mathrm{C} / \mathrm{R}=$ Cultivar directly buded on Prumus mahaleb

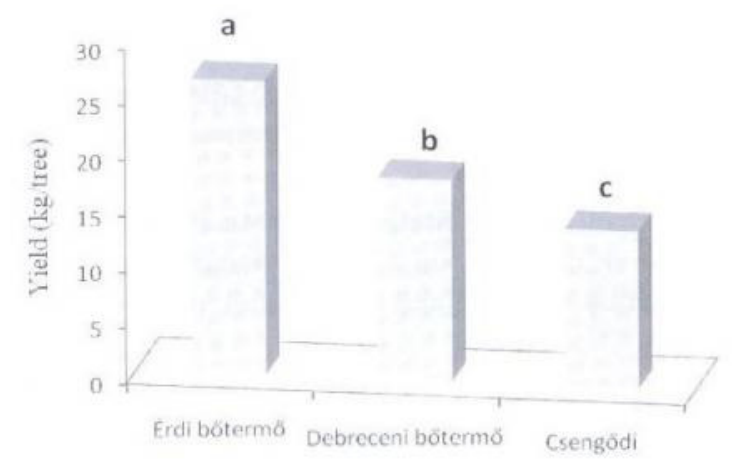

Figure 6. Specific yield $\mathrm{kg} /$ tree of sour cherry cultivars

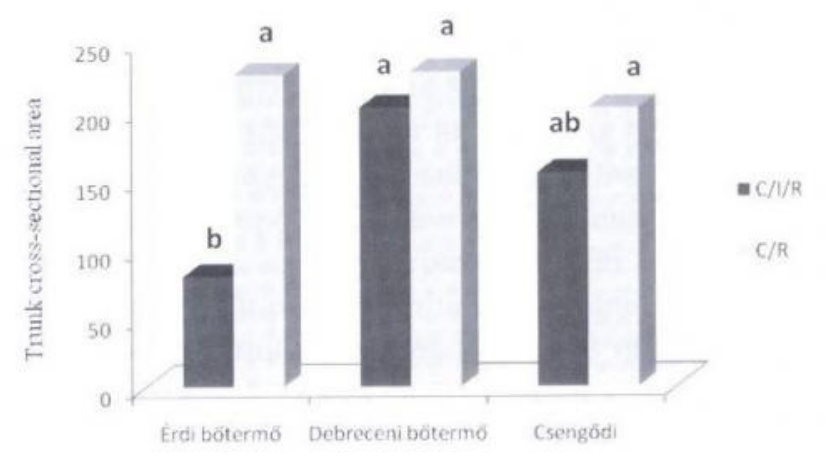

Figure 7. Effects of interstock on Specific yield $\mathrm{kg} /$ tree of sour cherry cultivars Legend: $C / 1 / R=$ Cultivar buded on Interstock which buded on Prumus mahaleb $\mathrm{C} / \mathrm{R}=$ Cultivar directly buded on Prumus mahaleb

the earliest reports on cherry rootstocks, citied by Anthony et al. (1937) and Webster \& Schmidt (1996), reported that interstocks improving the yield productivity of sweet cherry scions. The yield efficiency ( $\mathrm{kg}$ per tree) showed that the tree of Érdi bôtermố with interstock of Oblacsinska on Prunus mahaleb and also the tree grafted directly on Prunus mahaleb without interstock were more productive, but not significantly (Figures 6 and 7 ). This results are agree whit the results of Millikan \& Hibbard (1984) and Stebbins \& Cameron (1984). In their opinion rootstocks, interstocks and scions may effect several cherry tree yield and yield efficiency. 


\section{Conclusion}

It is well known that the use of interstock makes sweet cherry trees smaller and more productive in comparison to trees directly grafted on rootstocks. The results of this research is not consistent with general opinion. However some of the investigated interstock didn't reduce the growth of cherry trees and didn't improve their yields. Our results demonstrate that Oblacsinska as an interstock reduced the growth of trees and canpy volum. These kind of trees are suitable for intensive orchards,but the Interstems modified the tree size and yield of cultivars.

\section{References}

Anthony, R.D., Sudds, R.H. \& Yerkes, G.E. (1937): Orchard tests of Mazzard and Mahaleb cherry understocks. Proc. Am. Soc. Hortic. Sci., 35: 415-418.

Bujdosó G., Hrotkó, K. \& Stehr, R. (2004): Evaluation of sweet and sour cherry cultivars on German dwarfing rootstocks in Hungary. Journal of fruit and ornamental plant research 12: 233-244.

Bryant, L.R. (1939): Sour cherry rootstocks. Proc. Am. Soc., 37: 322-323.

Holb, I.J. Schnabel, G. (2005): Comparison of fungicide treatments combined with sanitation practices on brown rot blossom blight incidence, phytotoxicity, and yield for organic sour cherry production. Plant Disease. 89: 1164-1170.
Hrotkó, K. \& Simon, G. (1996): Effect of rootstock on the growth and prodetivity of sweet cherry trees. Acta Hort. 410. 519-525.

Hrotkó, K., Magyar, L., Simon, G. \& Hanusz, B. (1997): Effect of rootstocks and interstocks on growth and yield of sweet cherry trees. Acta Hort. 451. 231-236.

Hrotkó, K., Magyar, L. \& Simon G. (1998): Growth and productivity of sweet cherry interstem trees. Acta Horticulturae 468. 1: $353-362$.

Larsen F.E. (1970): A sweet cherry scion/interstock/rootstock experiment. Fruit var. Hortic. Dig. 24: 40-44.

Larsen, F.E. \& Patterson, M.E. (1981): Interstock/rootstock effects on Bing cherry fruit quality. Fruit Var. J., 35:23-25.

Millikan, D.F. \& Hibbard, A.D. (1984): Increased productivity of Montmorency tart cherry on WA 900 Mahaleb roots. Fruit Var. J. 38: $143-145$.

Rozpara, E., Grzyb, Z.S. \& Zdyb, H. (1998): Growth and fruiting of two sweet cherry cultivars with different interstems Acta Hort. 468: $345-352$.

Stebbins, R.L. \& Cameron, H.R. (1984): Performance of 3 sweet cherry, Prunus avium L., cultivars on 5 clonal rootstocks. Fruit Var. J. 38: 21-23.

Tabel E. (2005): A dwarf rootstock for intensive cherry orchards, Acta Hort. 217-221.

Webster A.d. \& Schmidt H. (1996): Rootstcks for sweet and sour cherries. (In: Cherries Webster, A.D. and Looney, N.E., Eds.). CAB International, Wallington, UK: 27-163.

Westwood, M.N., Roberts, A.N. \& Bjornstad, H.O. (1976): Comparison of mazzard, Mahaleb and hybrid rootstock for Montmorency cherry (Prunus cerasus L.). J. Am. Soc. Hortic. Sci., 101: 268-269. 